\title{
PERKEMBANGAN TERKINI PENELITIAN SASTRA AKADEMIK DAN NON AKADEMIK MENGHADAPI REVOLUSI INDUSTRI 4.0
}

\author{
The Latest Outgrowth of Academic Literature Research And Non Academic Literature
}

Research Facing Industrial Revolution 4.0

\section{Muhammad Fadli Muslimin ${ }^{\mathrm{a}}$}

${ }^{a}$ Ilmu Sastra, FIB, Universitas Gadjah Mada

fadlimuslimin@gmail.com

\begin{abstract}
Abstrak
Penelitan umumnya terbagi dua yaitu penelitian ilmiah dan non ilmiah yang dilakukan oleh masyarakat, perbedaan mendasarnya terletak pada proses mencapai hasil kajian tersebut atau yang biasa disebut sebagai persoalan metodoligis melibatkan teori dan metode. Penelitan adalah kegiatan yang dilakukan mengikuti kaidah ilmiah secara sistematasi untuk memperoleh informasi, data dan membuktikan kebenaran atau ketidakbenaran suatu asumsi ataupun hipotesis, khususnya penelitian sastra mengandung arti untuk mengetahui kekaburan elemen-elemen dalam karya satra dengan menghubungakannya dengan kerangka metode, teori yang tepat. Tujuan penelitian pada umumnya yaitu untuk mendesiminasikan gagasan ataupun hasil obeservasi terhadap suatu objek kajian sastra. Penelitian ini dapat dilakukan akademisi, praktisi dan masyarakat pada umumnya. Media untuk penelitian di era digital atau revolusi industri 4.0 telah berkembang dan mengalami pergeseran paradigma dalam hal desiminasinya. Wahana jurnal yang umumnya digunakan oleh peneliti akademsi dan praktisi sebagai ruang untuk menyebarluaskan hasil penelitiannya bagi khalayak pun telah bergeser dari paradigma cetak ke daring; penelitian nonilmiah pun yang dilakukan oleh masyarakat umum atau non akademik menunjukkan pergeseran yang lebih drastis dari sekedar blog kemudian bergerak pada wahana daring popular yang dikelola secara professional. Memandang bahwa wahana penyebarluasan ini berada dalam garis revolusi industry 4.0 yang berfokus pada pemanfaatan teknologi lebih maju yang lebih kompetitif dan berdaya saing mengantarkan pergeseran paradigma ini semakin mendapatkan ruangnya. Penelitian ini bertujuan untuk melihat perkembangan pergeseran wahana desiminasi penelitian sastra akademik dan non akademik di era revolusi industry 4.0. Metode yang dipergunakan yaitu metode penelitan deskriptif. Hasil penelitian ini adalah pergerakan desiminasi penelitian sastra akademik dan non akademik yang dilakukan masyarakat menunjukkan pergeseran paradigma yang tidak saja terjadi pada wahana desiminasinya tetapi juga pada penelitinya yang lebih bersifat universal.
\end{abstract}

Kata-kata kunci: Penelitiam, akademik, non-akademik, desiminasi, revolusi, industry 4.0 


\begin{abstract}
Research is generally divided into two, namely scientific research and non-scientific conducted by the community, the basic difference lies in the process of achieving the results of the study or commonly referred to as the problem methodology involves metodoligis and methods. Research is an activity that follows the scientific rules systematically to obtain information, data and prove the truth or untruth of an assumption or hypothesis, especially literary research has a meaning to know the blurring of elements in the work of satra by connecting it with the framework of method, correct theory. The purpose of research in general is to disseminate the idea or the results of obeservation of an object of literature review. This research can be done academicians, practitioners and society in general. Media for research in the digital age or industrial revolution 4.0 has evolved and experienced a paradigm shift in terms of its dissimination. The journal journals commonly used by academic researchers and practitioners as a space for disseminating research results to audiences have shifted from the print paradigm to online; non-scientific research conducted by the general public or non-academic shows a more drastic shift than just blogs then move on the popular online rides that are managed professionally. Considering that this spreading vehicle is within the line of the 4.0 industry revolution focusing on the use of more advanced, more competitive and competitive technologies, this paradigm shift gains more space. This study aims to see the mapping of the shifting rides for the dissemination of academic and non-academic literary research in the era of industry revolution 4.0. The method used is descriptive research method. the results of this research is the movement of dissemination of academic and non academic literature research conducted by the community showed a paradigm shift that not only happened in the sphere of desimination but also on the more universal researchers.
\end{abstract}

Keywords: scientific, research, dissemination, industrial revolution 4.0

\title{
PENDAHULUAN
}

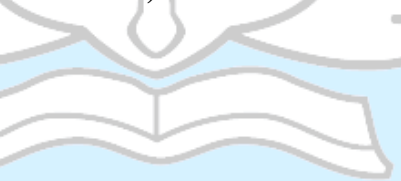

Kritik sastra Akademik mengemuka akhir tahun 1960-an dipelopori pergulutan yang terjadi antara pengikut golongan kritik sastra Ganzheit dengan pengikut golongan sastra akademik yang dikenal sebagai kritik sastra Rawamangun. Di antara tokoh kritik sastra Ganzheit itu adalah Arief Budiman dan Goenawan Mohammad; sedangkan kritikus aliran Rawamanganun di antaranya ialah M.S. Hutagalung, J.U. Nasution, M.Saleh Saad, dan Boen Sri Oemarjati (Pradopo, 2012). Edisi panjang pergulatan ini berujung pada dipertemukannya kedua kelompok kritikus dalam berbagai forum yaitu pada tahun 1978 Tentang Kritik sastra : Sebuah Diskusi dan pertengahan tahun 1970-an polemik antara M.S Hutagalung dengan Arif Budiman dibukukan dengan judul Kritik atas Kritik atas Kritik (1975). Selanjutya, di 
akhir tahun 1972 Dewan Kesenian Jakarta juga mengadakan diskusi sastra dengan tema perbandingan metode kritik sastra Ganzheit dengan kritik analitik. Tahun 1980-an, gejolak teori sastra dan krtik sastra barat memasuki babak baru yang lebih kuat masuk ke dalam linkungan kritik sastra akadaemik. Pergulatan terjadi dengan hasrat untuk membentuk teori sastra dan kritik sastra sendiri yang khas Indonesia. Pada tahun 1988, Subagio Sastowardoyo membuat renungan "Mencari jejak Teori Sastra Sendiri” yang disampaikan di Universitas Bung Hatta Padang dalam agenda Seminar Susastra Indonesia 23-26 Maret. Subagio menawarkan 5 prinsip teori yang seharusnya diperhatikan, yaitu bersifat umum, Eksplisit, falsifikasi, kogerensi, dan sahaja (Suroso, 2015)

Kedua aliran kritik tersebut mengalami pergulatan berdasarkan pandangan mengenai keilmiahaan suatu kritik sastra terhadap karya sastra. Arief Budiman memberikan tanggapannya terhadap tulisan S. Effendi ‘TENTANG KRITIK SASTRA Sebuah Pendirian’ yang menyatakan bahwa apabila sejumlah teori atau kaidah-kaidah diatas dapat dicek kebenarannya pada cipta sastra apa pun, maka telaah tentang cipta sastra adalah ilmu. Jika tidak, dia bukan ilmu(Effendi, 1978:20). Pandangan tersebut ditegaskan kembali bahwa kritik sastra yang dimaksud oleh Effendi lebih ditekankan pada sarjana sastra, dalam penelitiannya terhadap karya-karya sastra atau pembahasan sastra dalam lingkungan akademis. Pada gilirannya, Arif Budiman merespon pernyataan Effendi dengan mengatakan bahwa kritik bukanlah penelitian. Kritik ialah pengungkapan kembali pengalaman estetis (Budiman, 1978:37). Hal ini bermuara pada kefokusan pada aturan baku yang ditetapkan secara ilmiah melalui pedoman-pedoman penulisan yang berasaskan pada metode dan teori yang berlaku sedangkan kritik sastra nonakademik memanfaatkan metode dan teori secara bebas sesuai dengan aliran kepenulisan masing-masing penulis dan cenderung memanfaatkan bahasa populer sebagai wadahnya.

Kecenderungan tersebut membuka ruang lainnya untuk ditelaah lebih jauh yaitu media desiminasi terhadap penelitian yang dilakukan melalui kedua perspektif tersebut. Polarisasi yang berkesinambungan mengalami transformasi wajah media yang menaungi eksistensi diseminasi gagasan tersebut di masyarakat. Kritik sastra akademik berada tetap dengan jalur keilmiahan yang diterapkan pada analisis terhadap karya sastra begitupun juga kritik sastra nonakademik. Dalam perkembangannya, keduanya menunjukkan wajah baru 
seiring perkembangan zaman terutama berkaitan dengan pemanfaatan teknologi secara luas dalam rangka disemenasi kritik sastra melalui ruang publikasinya masing-masing. Kritik sastra akademik memanfaatkan jurnal dan kritik sastra nonkademik memanfaatkan portal daring populer

Kedua aliran tersebut sejatinya tidak lagi berada dalam tataran perseteruan mengenai siapa yang layak menempati posisi puncak kritik sastra yang relevan bagi masyarakat Indonesia khususnya akademisi, pegiat, penikmat, pecinta, dll sastra untuk mencerdaskan masyarakat melalui sastra; melainkan telah mengalami pergeseran ke sebuah babak baru yaitu pertarungan Index dan impact factor ke pembacanya. Sebagaimana diungkapkan W.H Hudson adalah fungsi yang terutama bagi kritik ialah memperjelas dan memberi dorongan. (Pradopo, 2007:18) artinya adalah kritik sastra menjadi sebuah wadah untuk mengungkapkan makna yang samar-samar yang dituliskan oleh penulis sehingga nilai-nilai yang terkandung dalam karya sastra dapat diejawentahkan dan dikonsumsi oleh pembacanya. Dengan menepatkan kritik sastra bersanding dengan karya sastranya, hal tersebut menajamkan kepandaian pembaca dalam mencerna isi karya sastra. Hal tersebut dapat diterjemahkan sebagai bagaimana kritik dapat menunjukkan kekuatannya dalam mempengaruhi pembaca untuk mengungkapkan makna dalam karya sastra.

Aliran kritik sastra akademik dan non akademik di era kontemporer merujuk kepada penelitian-penelitan sastra memanfaatkan metodologi ilmiah dalam kajiannya dan yang tidak memanfaatakn metodologi dalam kajiannya. Perkembangan selanjutnya di era revolusi industri 4.0, setidaknya menyebabkan gegar teknologi dimana setiap instansi ataupun institusi mempunyai tanggung jawab untuk mewadahi hasil penelitian masyarakat melalui wadah-wadah daring yang dapat dijangkau oleh masyarakat luas, yaitu jurnal untuk penelitian ilmiah dan portal-portal daring popular untuk penelitan non-ilmiah.

Di era Revolusi Industri 4.0 wahana desiminasi penelitian berbasais ilmiah ataupun non ilmiah sebagaimana yang terjadi di kalangan masyarakat tekait kajiannya pada karya sastra atupun fenomoena yang menyertainya telah mengalami pergeseran yang cukup signifikan. Perkembagan yang siginifikan dan progresif ditunjukan oleh pergerakan wahana jurnal-jurnal nasional di Indonesia memanfaatkan Open Jurnal System yang dikelola secara 
ilmiah oleh Jurnal manajer yang tentunya ahli di bidangnya dan juga portal-portal daring yang memuat penelitian-penelitan nonilmiah.

Hal ini dapat terlihat dari salah satu indikator yang dapat dijadikan pertimbangan yaitu kemampuan wahana diseminasi untuk menjangkau pembacanya dan hal tersebut jika ditinjau dari paradigma lama maka bertumpu pada kuantitas wahana yang mampu diperjualbelikan oleh penerbit sehingga dapat menjangkau pembacanya sedangkan salah satunya dapat ditnjau dari jumlah pembaca yang membaca hasil kritikan tersebut secara daring. Bagi kritik sastra di kedua aliran, keberadaan kritik mempunyai dampak kepada pembacanya yang ditinjau dari wadah pengindex bagi masing-masing dan sejauh mana komunikasi antar kritik terjadi.

\section{LANDASAN TEORI}

Impact Factor adalah sebuah alat ukur untuk mengetahui frekuensi rata-rata artikel dalam sebuah jurnal disitasi dalam suatu waktu tertentu. ini bergunan untuk mengukur pentingnya sebuah jurnal dengan mengkalkulasi waktu artikel-artikel tersebut disitasi. Impact Factor hanya salah satu alat untuk pemeringkatan, evaluasi, kategorisasi dan perbandingan jurnal yang disedikan oleh Journal Citation Reports (JCR). Impact Factor berguna dalam memastikan jumlah mutlak frekuensi jurnal. Secara umum Impact Factor memberikan ruang pada pustakawan dan peneliti sebagai alat untuk manajemen koleksi jurnal perpustakan. dalam riset pasar, Impact Factor menyedikan bukti kuantitatif untuk editor dan penerbit untuk memposisikan jurnal mereka kaitannya dengan kompetisiterutama jurnal dalam kategori yang sama. Penggunaan dewasa ini, Impact Factor berada pada proses evaluasi akademik. Impact Factor digunakan untuk memberikana perhitungan awal mengenai prestisi atau derajat jurnal yang didalamnya individu mempublikasikan tulisannya. Artinya adalah kualitas dari sebuah artikel ditentukan oleh Impact factornya, semakin tinggi impact factor yang didapatkan oleh artikel dalam sebuah jurnal melalui sitasi semakin tinggi pula derajat atau prestige yang didaptkan oleh jurnal maupun artikel yang berada didalamnya (Garfield, 1998)

Index atau Journalh-Index adalah suatu pengukuran kualitas dari sebuah jurnal yang dapat dikalkulasikan menggunakan data dari web of science, scopus atau Google scholar dan Sinta. Index membantu jurnal memperoleh tujannya untuk dapat diakses secara luas oleh 
masyarakat. Akses yang mudah terhadap jurnal akan berdampak pada reputasi jurnal sebagai sumber informasi berharga dalam bidangnya masing-masing yang dapat diandalkan. Di Indonesia, Jurnal-Jurnal perlu mendaftarkan pada lembaga pengindex nasional ataupun internasional agar index dan impact factor nya dapat terlihat dan nyata.

Impact Factor dan Index diterjemahkan secara non akademik dapat berarti sebagai dampak yang disebabkan oleh sebuah artikel sehingga penulis lain melakukan sebuah pembacaan dan kemudian mensitasi artikel tersebut untuk keperluan publikasi lainnya dan Index adalah wadah bagi tulisan-tulisan non akademik untuk mendapatkan pengakuan nasional maupun internasional untuk berkontestasi dalam sebuah publikasi populer yang menggunakan portal-portal online, portal online memiliki kedudukan yang setara dengan Jurnal dalam hal ini terkait dengan wadah bagi kritik sastra akademik dam non akademik sebagai ruang publikasinya. Tulisan-tulisan non akademik yang memuat kritik-kritik sastra dijadikan tinjauan dalam melihat perkembanga selanjtunya dari budaya kritik sastra di Indonesia pada portal online ini. Impact factor menjadi sebuah indikator dasar melihat kemajuan kritik sastra terkait kunjungan yang dilakukan oleh pembaca secara daring untuk menikmati kritik-kritik sastra tersebut dan Index merupakan ruang bagi kritik-kritik sastra nonakademik menempatkan tulisan-tulisannya terindex sehingga mempunyai reputasi secara nasional maupun internasional dan mendapatkan pengakuan tetapi sejauh ini belum ditemukan platform pengindex portal online sebagaimana yang diterapkan pada jurnal-jurnal berkala ilmiah yang mempunyai platform index seperti di Scopus, Elsevier, Ebsco, Proquest, IPI, Sinta dll.

\section{METODE PENELITIAN}

Penelitian ini merupakan penelitian deskriptif kualitatif yang memfokuskan pada pengungkapan kondisi penelitan sastra akademik dan nonakademik yang dilakukan oleh masyarakat. Data yang dikumpulkan melalui telaah terhadap beberapa penelitian terkait yang menekankan pada perkembangan kedua tradisi penelitian tersebut. Selanjutnya, penulis mendekati fenomena tersebut dengan mempertimbangkan perkembangan teknologi pada era revolusi Industri yang memiliki kecenderungan pergeseran paradigma terkait diseminasi penyebaran penelitian tersebut. Data selanjutnya dianalisis dengan mempertimbangkan 
tujuan dari Impact Factor dan Index; dan tidak melakukan analisis lebih jauh terhadap penghitungan sitasi terhadap karya-karya tersebut.

\section{PEMBAHASAN}

\section{Diseminasi Penelitian Sastra Akademik dan nonakademik}

Sejarah mengungkapkan bahwa kritik sastra Indonesia modern mengalami transformasi wajah. Dalam Buku Kritik Sastra Indonesia Modern dinyatakan bahwa Kritik sastra Indonesia modern awalnya ditulis oleh para sastrawan sejak periode balai pustaka sampai dengan periode Angkatan 45 setelah itu pertengahan tahun 1950-an wajah baru ditunjukkan oleh kalangan akademik di lingkungan Universitas melalui penulisan kritiknya yang dikenal juga dengan kritik akademik. Para sastrawan tetap menuliskan kritik terhadap karya sastra. Meskipun demikian, antara tahun 1956 sampai dengan 1988 penelitian kritik sastra akdemik tetap mendominasi.

Kritik sastra akademik terutama ditunjukkan pada awal tahun 1960-an yang dipelopori oleh M.S Hutagalung, J.U. Nasution, M.Saleh Saad, dan Boen Sri Oemarjati hingga pertengahan tahun 1988. Di lingkungan akdemik, respon yang ditunjukkan yaitu dengan diadakannya Seminar Sastra di Universitas Bung Hatta sebagai respon positif terhadap arus teori sastra dan kritik sastra barat yang masuk ke Indonesia. Klaim terhadap kritik sastra akademik sebagai wujud kesewenang-wenangan akademisi menjadi perdebatan dikalangan sastrawan dimana karya sastra dianggap sebagai jasad tak berjiwa, kritikus melakukan anatom atas jasad tersebut dengan memenggal bagian-bagian karya sastra dan akibatnya tugas kritik akademis seolah-olah hanya melakukan pencabikan atas sebuah teks sastra (Mahayana, 2009) Anggapan tersebut dapat dikatakan sebagai pernyataan yang tepat jika merujuk kepada bagaimana akademisi membuat sebuah kritik terhadap sebuah karya dengan memfokuskan kepada sebuah objek formal tertentu yang hendak dijadikan fokus kajian sehingga hasil kritikan berupa fragmen-fragmen yang menyisakan ruang untuk dikaji oleh akademisi lainnya.

Akademisi memanfaatkan karya sastra sebagaimana jasad yang selanjutnya dibedah secara parsial dan diteliti bagian-bagian tertentu saja dan tidak menyeluruh. Hal ini terwujud 
dalam sebuah penelitan yang dilakukan oleh Tirto Suwondo ${ }^{1}$, makalah yang berjudul Kritik Sastra Indonesia dalam Jurnal Humaniora tahun 2000-2008 mengungkapkan bahwa para kritikus akademis membedah karya sastra secara parsial dan tidak menyeluruh mengupas seluruh isi dalam sebuah novel yang dikritiknya; Sariyati Nadjamuddin Tome yang meneliti Novel La Barka karya Nh. Dini mengupas karya tersebut dari perspektif feminisnya saja; Putera Manuba mengupas Novel-Novel Pramoedya Ananta Toer : Refleksi Pendegradasian dan Interpretasi Makna Perjuangan Martabat Manusia (Suwondo, 2010). Meskipun demikian, tujuan dari pembedahan yang tidak menyeluruh tersebut untuk membangun orientasi tersendiri terhadap penelitan yang dilakukan terhadap karya. Kritikan utama yang hendak disampaikan adalah bagaimana sebuah kritik terfokus pada hal-hal tertuju pada karya dan hal-hal yang berada di luar karya dengan memanfatkan pendekatan tertentu sehingga tidak menjangkau secara keseluruhan aspek yang hendak diteliti dalam karya sastra melalui kritik dikarenakan objek yang hendak dikritik dalam karya sastra memiliki banyak dimensi, aspek dan unsur.

Lingkup kritik Sastra Akademik tidak saja terbatas pada makalah ilmiah berupa skripsi, tesis, disertasi sastra ataupun berupa tugas-tugas akademik sastra lainnya yang menggunakan kritik sastra sebagai studi utamanya, melainkan telah merambah ke arah yang lebih luas yaitu wahana daring yang diwujudkan melalui Jurnal-jurnal yang dikelola secara ilmiah. Jurnal nasional dimanfaatkan sebagai ruang akadamik ilmiah untuk mempublikasikan tulisan ilmiah dalam hal ini kritik sastra yang ditempuh melalui sistematika yang telah diterapkan masing-masing jurnal tanpa mengabaikan kaidah-kaidah keilmiahan dalam menghasilkan sebuah kritik yang diterbitkan oleh perguruan tinggi,lembaga penelitian dan pengembangan, atau profesi ilmiah yang bertujuan untuk meregistrasi kegiatan kecendikiaan, menyertifikasi hasil kegiatan yang memenuhi persyaratan ilmiah, mendesiminasikannya secara meluas kepada khalayak ramai, dan mengarsipkan semua temuan hasil kegiatan kencendikiaan ilmuawan dan pandit yang dimuatnya ${ }^{2}$. Trend menggunakan jurnal sebagai database publikasi bukanlah sesuatu yang baru dalam dunia sastra akademik di Indonesia tercatat tahun 1989 Fakultas Ilmu Budaya Universitas Gadjah Mada melahirkan Jurnal

\footnotetext{
${ }^{1}$ Peneliti Madya Pada Balai Bahasa Yogyakarta

2 Permen No 22 Tahun 2011 Tentang Terbiatan berkala ilmiah
} 
Humaniora ; Tahun 1999 Fakultas Ilmu Budaya Universitas Indonesia menerbitkan Wacana : Jurnal Ilmu Pengetahuan Budaya; Tahun 2002 Adabiyyat : Jurnal Bahasa dan Sastra diterbitkan oleh Jurusan Sastra dan Bahasa Arab Fakultas Adab dan Ilmu Budaya UIN Sunan Kalijaga Yogyakarta; Tahun 2005 Jurnal Lingua diterbitkan oleh Fakultas Humaniora UIN Maulana Malik Ibrahim Malang.

Krtik Sastra nonakademik dengan tokoh awalnya yaitu Arif Budiman merespon golongan kritikus sastra dengan dasar-dasar teoritis dalam telaah sastra yang diusung oleh kelompok Rawamangun dengan megemukakan sebuah metode Ganzheit yang menekankan pada pendekatan subyektif, tanpa prasangka, dan pengahayatan terhap karya seni sebagai suatu keutuhan baik bagi pembaca maupun kritikus(Teeuw, 1989). Metode ini diterapkan langsung olehnya pada sebauh skripsi yang ditulisnya di bidang psikologi di Universitas Indonesia 1971 dan diterbitkan ulang tahun 1976 dengan judul Chairil Anwar, Sebuah Pertemuan. Metode yang dikemukakan oleh Arif Budiman ditinjau secara teoritis dianggap tidak memenuhi pedoman untuk dianggap sebuah telaah sastra yang mengandalkan objektifitas dalam melihat karya sastra karena bagi Arif Budiman metode ini ditentukan oleh pertemuan pribadi antara pembaca dan penyair, yang pada prinsipnya adalah mempribadi dan subyektif, paling penting adalah kedalaman dan kemurniaan penghayatan.

Oleh karena itu, kritik sastra nonakademik memanfaatkan ruang media seperti Koran, majalah, bulletin, esai-esai yang dibukukan sebagai sarana publikasi perluasan gagasangagasannya mengenai kritik sastra sehingga dapat dikomsumsi pembacanya. Meskipun demikian, dalam perkembangannya, kritik sastra nonakademik bermain dalam ruang populer yang mempunyai pembacanya tersendiri yang tidak saja dinikmati oleh kalangan akademis, tetapi juga diluar kalangan itu yaitu masyarakat secara umum. Ruang Sastra pada umumnya pada tahun 1970-an yaitu surat kabar Sinar Harapan, Pikiran Rakyat, suara karya dan Kompas ; majalah sastra Horison , budaya Jaya dll. Perkembangan media publikasi kritik sastra nonakademik semakin meluas dan menjangkau pembacanya semakin efektif seiring dengan perkembangan teknologi informasi. Jangkuan Publikasi kritik-kritik nonakdemik tidak saja memanfaatkan wahana koran, majalah, buletin cetak melainkan bergeser menggunakan portal-portal online. Hal ini tidak terlepas dari pergeseran pemanfataan teknologi di era revolusi indutri 4.0 yang menstimulus pergeseran wahana cetak ke wahana 
daring. Portal yang dimksud sebagai contoh yaitu www.jendelasastra.com, www.litera.co.id, www.infosastra.com,www.sastranesia.com/,www.duniasastra.com, www.pawonsastra.com, dan www.majelissastra.com dll.

Tidak hanya kritik sastra akademik yang mengalami perkembangan wahana publikasi berupa jurnal, tetapi kritik sastra nonakademik pun demikan mengalami perkembagan serupa yang awalnya memanfaatkan media cetak kemudian beralih ke wahana daring melalui portalportal online. Pertanyaan selanjutnya yang mengemuka adalah apakah kritik sastra melalui wahana baru tersebut dapat terfasilitasi? adakah ruang-ruang bagi kritik sastra bernaung sehingga dapat dinikmati gagasan-gagasannya baik melalui jurnal maupun portal-portal daring?

\section{Wahana Diseminasi Penelitian Sastra Di Era Revolusi Industri}

Kementrian Industri Republik Indonesia dalam sebuah nasional seminar Outlook Indusry 2018 "Bringing the Fourth Industrial Revolution to Indonesia 11 Desember 2017 memaparkan mengenai Indonesia yang telah memasuki babak baru revolusi industry yang keempat setelah revolusi industri 1.0 diakhir abad ke-18 berfokus pada fasilitas produksi mekanik menggunakan air dan kekuatan mesin uap; revolusi industry 2.0, Awal abad ke-19, memperkenalkan mengenai mesin produksi massal berdasarkan pada tenaga kerja; Revolusi industry 3.0 adalah era penggunana alat-alat elektronik dan teknologi informasi untuk lebih lanjut melakukan produksi; revolusi industry 4.0 menekankan pada konektivitas orangorang, mesin-mesin, dan internet ada dimana-dimana. Revolusi industry 4.0 menekankan pada lima kunci teknologi utama yang berkembagn pesat yaitu Artificial intelligence $(A L)$, Internet of Things (IoT), Advanced Robotics, Werables/Augmented Reality/Virtual Reality. dan $3 D$ Printing.

Dalam kerangka tersebut, memandang Revolusi Industri 4.0 dengan kunci poin perkembangannya dan kedudukan penelitian sastra, yaitu terletak pada desiminasi penelitian akademik ataupun non akademik yang memanfaatkan Internet of Things (IoT), IoT adalah sebuah sistem yang menggambarakn dimana item-itemnya di dunia fisik terhubung melalui internet melalui jaringan wireless dan Internet jaringan kabel (An Introduction to The Internet of Things (IoT), 2013). Hal ini mengandung arti bahwa wahana desiminasi penelitian sastra telah memasuki era digital dimana dalam proses pengelolalannya pun menuntut pemahaman 
teknologi informasi sekaligus pemahaman keilmuan utama yang memadai untuk mengolah hasil penelitian secara daring sekaligus ilmiah. Oleh karena itu, pemerintah mersepon cepat dengan mengeluarkan peraturan Menteri Pendidikan Nasional Republik Indonesia Nomor 22 Tahun 2011 terbitan berkala ilmiah, dilanjutkan Peraturan Direktur Jenderal Pendidikan Tinggi Kementrian Pendidikan dan Kebudayaan Republik Indonesia Nomor 1 Tahun 2014 tentang Pedoman Akreditasi Terbitan Berkala Ilmiah dimana terbitan berkala ilmiah yang semula tercetak beralih kepada elektronik menggunakan wahana Open Jurnal System atau yang setara untuk memproses tulisan secara cepat dan dapat disunting, ditelaahn dan diterbitkan mengacu pada standar ilmiah. Peraturan terbaru yang dikeluarkan oleh Menteri Riset, Teknologi, dan Pendidikan Tinggi Republik Indonesi Nomor 9 Tahun 2018 tentang Akreditasi Jurnal Ilmiah Bab 2 Pasal 1 No 1 Jurnal Ilmiah adalah bentuk pemberitaan atau komunikasi yang memuat karya ilmiah dan diterbitkan berjadwal dalam bentuk elektronik dan/atau tercetak.

\section{Direktori Kritik Sastra Akademik Dan Nonakademik}

Budaya publikasi ilmiah melalui jurnal-jurnal akademik telah memasuki ketahap sistematis dan terstuktur sehinggi akademis, peneliti, pegiat yang hendak mempublikasikan hasil temuannya mengikuti aturan-aturan ataupun pedoman baku yang diterapkan pemerintah melalui Peraturan Menteri Pendidikan Nasional Republik Indonesia Nomor 22 Tahun 2011 sehingga penulis diwajibkan untuk berafiiasi dengan perguruan tinggi, lembaga penelitian dan pengembangannyaa, organisasi profesi atau industri. Artikel yang dimaksud adalah artikel yang secara nyata memajukan pengetahuan, ilmu, teknologi, dan/atau seni yang didasarkan pada hasil penelitain dan telaah yang mengandung temuan dan/atau pemikiran orisinil serta bebas plagiarism.

Beranjak dari hal tersebut, secara umum publikasi yang memuat artikel ilmiah gagasan-gagasanya haruslah menempuh pedoman-pedoman keilmiahaan sehingga dapat memberikan dampak nyata dalam bidang ilmu pengetahuan dan seni dalam hal ini terkait sastra khususnya kritik sastra. Lebih lanjut, untuk mewadahi publikasi tersebut maka keberadaan jurna ilmiah menjadi pilihan yang tidak dapat terhindarkan karena regulasi telah ditetapkan secara langsung oleh pemerintah dan dikalangan akademik wajib ditaati setiap poin-poinnya. Agar memperoleh legalitas dari pemberi kebijakan dan sebagai respon 
terhadap publikasi artikel ilmiah tersebut maka keberadaan jurnal-jurnal ilmiah penting adanya karena memberikan wahana publikasi bagi artikel-artikel tersebut.

Jurnal-jurnal bidang sastra menjadi wahana akademik untuk publikasi hasil telaah sastra. Di Indonesia terdapat beberapa Jurnal-Jurnal bereputasi yang menjadi wahana publikasi, antara lain Jurnal Humaniora FIB UGM, Wacana : Jurnal Ilmu Pengetahuan Budaya FIB UI; TAdabiyyat : Jurnal Bahasa dan Sastra Jurusan Sastra dan Bahasa Arab Fakultas Adab dan Ilmu Budaya UIN Sunan Kalijaga Yogyakarta; Jurnal Lingua diterbitkan oleh Fakultas Humaniora UIN Maulana Malik Ibrahim Malang dll. Penulis-Penulis mengirimkan naskahnya ke jurnal-jurnal tersebut untuk selanjutnya melalui proses penyuntingan yang dilakukan oleh ahli-ahli dibidangnya, berprofesi sebagai dosen-dosen berdisiplin ilmu sastra sehingga artikel tersebut siap untuk dipublikasikan.

Melalui publikasi jurnal kajian-kajian sastra hidup dikalangan akademik dan bagi pembaca secara umum tetapi apakah ruang tersebut dimanfaatkan bagi para akademisi untuk memperkaya khasanah kritik sastra. Penelusuran secara daring yang dilakukan melalui http://id.portalgaruda.org dengan mengetikkan kata kunci "Kritik Sastra" menunjukkan terdapat 42 artikel yang mengulas mengenai kritik sastra yang dimuat di Jurnal Humaniora , Jurnal IBDA, Jurnal SulukIndo, Jurnal Barada, Jurnal Bahasa dan Sastra, Wacana :jurnal of the humanities of Indonesia, Lingua, Bahtera Sastra : Antologi Bahasa dan Sastra Indonesia, Jurnal Pendidikan Bahasa dan Sastra, Jurnal Mahasiswa FIB, Palasteran, Parafrase, Kreatif, Jurnal Ilmu Sosial dan Humaniora, Jurnal Sosioteknologi, Bahastra Jurnal Ilmiah Bahasa dan Sastra,Jurnal Pujangga, Jurnal Kajian Bali, Atavisme Jurnal Ilmiah Sastra, Edu Lingua, Jurnal Pendidikan, Diksi, Sawo Manila,Poetika, Jurnal Humanika, Dialektika. Kombinasi kata yang berbeda dapat memunculkan hasil yang berbeda.

Jurnal yang memuat artikel kritik sastra tertua yaitu pada tahun 1993 yang ditulis oleh Suminto A Sayuti dengan judul Kritik Sastra : Sebuah Tinjauan Umum dan yang terbaru yaitu tahun 2015 oleh Asep Anugerah dengan judul Mitos Kecantikan Dalam Cerpen Barbitch Dan Lipstik Merah Tua Karya Sagita Suryoputri (Telaah Kritik Sastra Feminisme) diterbitkan oleh Journal Pendidikan Bahasa Dan Seni FKIP UHO . Kehadiran jurnal-jurnal beserta artikelnya tersebut ditinjau secara historis dan kuantitas dapat dikatakan belum 
mencapai sebuah tahap dimana kritik sastra telah dilaksanakan oleh akademis secara bertahap dengan baik dan rutin mengingat aktifitas-aktifitas diperguruan tinggi yang sejatinya memberikan ruang yang lebih untuk menghadirkan kritik-kritik sastra secara berkesinambungan dan historis.

Meskipun kritik sastra nonakademik tidak mempunyai sistem pengindex sebagaimana jurnal-jurnal yang melalui peraturan pemerintah menghadirkan lembagalembaga pengindex nasional secara daring tetapi kehadiran portal-portal online dapat menjadi ruang efektif dan mempunyai pembacanya tersendiri baik dari kalangan akademik maupun nonakdemik pun demikian dengan jurnal. Portal-portal daring secara spesifik menyediakan kandugnan informasi yang dapat diakses diberbagai perangkat dan menyediakan ruang desiminasi gagasan-gagasan mengenai sastra khususnya kritik sastra. Situs-situs web demikan dibangun dan didesain berdasarkan kesamaan selera kolektif suatu jejaring masyarakat dan fasilitas-fasilitas yang digunakan menunjang untuk mewadahi minat dan kebutuhan pembacanya.

Portal-portal daring yang mengusung tema sastra sebagai topik utamanya ditulusuri secara daring dapat menunjang ruang-ruang bagi penulis ataupun kritikus yang hendak mendesiminasikan hasil telaahnya mengenai spesialis topik tertentu baik itu berupa berita terbaru sastra, karya sastra berbentuk drama, prosa, puisi, sastra lama, artikel, poko dan tokoh,essai, kritik, resensi, kamus sastra dll. www.jendelasastra.com pertama kali rilis Juni 2009 dengan pimpinan redaksi Ombi Ramli adalah salah satu portal daring yang memberi ruang bagi masyarakat Indonesia untuk menyalurkan sekaligus menambah wawasan kesusastraan Indonesia, mengekspresikan gagasan baik dalam bentuk karya sastra, kritik, maupun essay dan tidak hanya itu pengunjung juga dapat melakukan diskusi, mengomentari, dan berbagai dengan pengunjung lain.

Litera.co.id dilahirkan oleh lembaga literasi Indonesia April 2016 dengan dewan redaksi Ahmad Yosi Herfanda, Maman S. Mahayana, Mustafa Ismail, Sihar Ramses Simatupang. Terdapat beberapa ruang aspirasi dalam portal tersebut yaitu puisi, puisi pilihan, cerpen, cerpen pilihan, esai sosok, sajak, dan peristiwa. Pawonsastra.com terbit pertama kali Januari 2007 dalam bentuk buletin pawon yang didirikan dan diduking oleh sejumlah komuniatas sastra di Solo, dalam perkembangannya tidak hanya penerbitan melainkan 
mengadakan diskusi, workshop penulis, kelas menulis, workshop penulisan, pentas seni dan sastra, dan terakhir merilis portal online; dewan redaksinya antara lain Yudhi Herbibowo, Bandung Mawardi, Indah Darmastuti, Puitri Hati Ningsih, Yunanto Sutyastomo, Fany Chitmah, dll; pawon sastra memberikan ruang aspirasi berupa Acara, Biografi, Buletin, Cerpen, Ebook, Esai, Film, Info, Kisah Buku, Kolom Akhir, Puisi, Reportoar, Video dan Wawancara.

Tidak hanya ketiga portal daring tersebut yang berkembang dan tumbuh di Indonesia sebagai ruang nonakademik bagi penulis untuk menuangkan aspirasi tetapi juga masih banyak portal-portal lainnya yang mempunyai aspirasi yang serupa yang dikelola secara professional yang mempunyai struktur lengkap dan dinaungi oleh lembaga-lembaga tertentu maupun yang sifatnya independen diantaranya adalah sembahyangrumputan.com, majelissastra.com, kalaliterasi.com, haripuisi.com, titiknol.com, floressastra.com, mediasastra.com dll. Portal-portal online tersebut menyajkan telaah-telaah sastra terbaru dan kontekstual, jendelasastra.com oleh Rendy Ferdiansah mempublikasikan tulisannya yaitu Kritik Sastra Strukturalisme meskipun terlihat dalam tulisan tersebut lebih dekat kepada tulisan akademik daripada kritik sastra nonakademik; Fahrudin Nasrullah menukiskan tentang esais, Tukang Cerita, Hingga Kritik Sastra. Tulisan tersebut pun tampak hanya sebagai pemaparan umum engeai esais hingga kritik sastra; selanjutnya oleh Baban Banita dengan artikel Menelusuri akar kematian kritk sastra Indonesia : dalam Matinya Dunia Sastra : Biaografi Pemikiran dan catatan karya sastra Indonesia Karya Acep Iwan Saidi, tulisan ini mengulas tentang buku yang diterbitkan oleh Acep Iwan Saidi.

\section{Index dan Impact Faktor}

Indeks-h (bahasa Inggris: $h$-index) merupakan indeks yang mencoba untuk mengukur baik produktivitas maupun dampak dari karya yang diterbitkan seorang ilmuwan atau sarjana. Indeks ini didasarkan pada jumlah karya ilmiah yag dihasilkan oleh seorang ilmuwan dan jumlah sitasi (kutipan)p yang diterima dari publikasi lain. Dengan kata lain index adalah sebuah alat dimanfaatkan secara daring bagi para peneliti atau pustakawan untuk menemukan konten Imiah. Index mempunyai kemampuan untuk membuat sebuah publikasi mempunyai daya produktivitas baik ataukanh tidak ditinjau sejauh mana 
jumlah karya yang dihasilkan dan sitasi atau kutipan yang telah diperoleh penulis melalui tulisannya.

Di Indonesia Index terhadap jurnal-jurnal dapat diketahui melalui Portal Garuda http://portalgaruda.org, Onesearch perpusanas http://onesearch.id/, Indonesian Citation Index http://citation.itb.ac.id/citeseerx/index, Pilnas Ristek http://pilnas.ristek.go.id/jurnal/, ISJD http://isjd.pdii.lipi.go.id/. Artikel-artikel yang terdapat pada jurna-jurnal yang terindex salah satu dari index nasional tersebut dapat dikatakan mempunyai reputasi dan sebagai sumber informasi yang dapat diandalkan sesuai dengan bidang keilmuaan ; dan jika sebuah jurnal ataupun artikel terindex di database yang terkenal hal tersebut akan meningkatkan aspirasi pembacanya. Jurnal yang terindex secara langsung ada yang menampilkan keseluruhan data artikel ataupun judul artikel beserta referensi.

Penelitan Sastra Akademik sebagai sebuah bentuk publikasi ilmiah yang diterbitkan melalui jurnal-jurnal Indonesia sejatinya telah terindex di salah satu alat pengindex nasional tersebut dan artinya telah mendapatkan legitimasi mengenai diseminasi artikel yang memuat kritik kritik sastra dan telah diauki secara nasional melalui sistem yang telah diterapkan oleh pemerintah melalui Perdirjen No 1 Tahun 2014 poin Lain-lain 3.1 No. 7 tentang tercantum dalam salah satu lembaga pengindex nasional, yang artinya setiap jurnal yang telah terdaftar di Jurnal yang telah terindex nasional otomatis artikel-artikel yand dimuat didalamnya masuk kedalam database pengindex tersebut.

Pada Artikel kritik sastra yang berjudul Karya Religius Danarto : Kajian Kritik Sastra Feminis Jurnal Humaniora Vol 15 No 12003 ditulis Oleh Peni Aji dengan jumlah total dikunjungi dan diunduh sejumlah 888 (Adji \& Adji, 2012). Kritik sastra yang ditulis oleh Siswo Harsono Ekokritik : Sastra berwawasan Lingkungan Jurnal Kajian Sastra Vol 32 No 12008 jumlah artikel ini dikunjungi tidak diketahui karena jrunal tersebut tidak menunjukkan jumlahnya tetapi dapat diamati melalui kunjungan yang dilakukan pembaca ke jurnal yaitu 5.974 sejak oktober 2015 (Harsono, 2008). Sistem index nasional tersebut menjadikan artikel-artikel kritik sastra dapat diakui secara nasional kontribusinya didalam dunia sastra khususnya di bidang akademik.

Sedangkan impact factor pada kritik sastra akademik terbatas pada sistem sitasi yang diterapkan pada setiap jurnal yang terindex pada database yang dapat dilihat pada 
googlescholar.com, semakin tinggi jumlah sitasi yang diperoleh sebuah jurnal semakin tinggi pul dampak ilmiah dari artikel tersebut.

Pada kritik sastra nonakademik, mendudukkannya pada pemanfaatan sistem index tersebut pada akhirnya oleh negara tidak memberikan ruang karena tidak terdapatnya sistem index serupa yang diterapkan oleh negara kepada portal-portal daring yang mengusung topik telaah sastra khususnya kritik sastra. Ruang tersebut dikelola secara professional oleh pegiat, aktivis, penikmat sastra ataupun komunitas-komunitas sastra yang memiliki perhatian lebih terhadap perkembangan dunia sastra. Tinjauan pada impact factor dilihat dari statistik jumlah pembaca portal-portal online tersebut dapat ditarik kesimpulan bahwa keberadaan portal daring sebagai wahana desiminasi kritik sastra berperan lebih luas dan menjangkau semua kalangan masyarakat termasuk akademik dan sekaligus menjadi pusat informasi kebaharuan perkembangan telaah sastra pada umumnya dan kritik sastra pada khusunya.

\section{KESIMPULAN}

Penelitian sastra akdemik dan nonakademik mengalami transformasi wajah wahana publikasi yang memberikan ruang bagi keduanya menyediakan kritik-kritik sastra. Penelitan sastra akademik dengan wahana Jurnal yang oleh pemerintah distandarkan keilmiahannya menggunakan lembaga pengindex nasional sehingga dampak ilmiahnya dapat dimanfaatkan baik bagi penulis, peneliti, dibidang sastra khususnya kritik sastra dan wahan bagi kritik sastra nonakademik bergeser dari wahana-wahana cetak memanfaatkan portal-portal online yang dikelola secara professional ataupun independen oleh pegiat, aktivis, akademisi, sastrawan dll sebagai upaya untuk mendeseminasikan telaah sastra khususnya penelitain sastra akademik agar dapat dikonsumsi secara daring oleh masyarakat Indonesia.

\section{DAFTAR PUSTAKA}

Adji, S. E., \& Adji, S. E. P. (2012). Karya Religius Danarto: Kajian Kritik Sastra Feminis. Humaniora, 15(1), 23-38. https://doi.org/10.22146/jh.v15i1.771

An Introduction to The Internet of Things (IoT). (2013). San Fransisco.

Budiman, A. (1978). Jawaban Terhadap Bandingan. In A. Lukman (Ed.), TENTANG KRITIK SASTRA Sebuah Diskusi (1st ed., pp. 37-39). Jakarta Pusat: Pusat Pembinaan dan Pengembangan Bahasa.

Effendi, S. (1978). TENTANGN KRITIK SASTRA Sebuah Pendirian Lagi. In L. Ali (Ed.), 
TENTANG KRITIK SASTRA Sebuah Diskusi (1st ed., pp. 13-27). Jakarta Pusat: Pusat Pembinaan dan Pengembangan Bahasa.

Garfield, E. (1998). THE USE OF JOURNAL IMPACT FACTORS AND CITATION ANALYSIS FOR EVALUATION OF SCIENCE. Philadephia: The Scientist. Retrieved from http://www.garfield.library.upenn.edu/papers/eval_of_science_CBE(Utah).html

Harsono, S. (2008). Ekokritik: Kritik Sastra Berwawasan Lingkungan. Kajian Sastra, 32(1), 31-50. Retrieved from https://ejournal.undip.ac.id/index.php/kajiansastra/article/view/2702/2607

Mahayana, M. S. (2009). Tentang Kritik Akademis. Retrieved May 18, 2018, from http://sastra-indonesia.com/2009/01/tentang-kritik-akademis/

Pradopo, R. D. (2012). Kritik Sastra Indonesia Modern (1st ed.). Yogyakarta: Gama Media. Suroso. (2015). Kritik Sastra Pintu yang Terbuka : Memelihara Warisan Sastra Indonesia. Bedah Buku: Kitab Kritik Sastra Karya. Maman S Mahayana. Bogor: Universitas Pakuan Bogor.

Suwondo, T. (2010). Kritik Sastra Indonesia dalam Jurnal Humaniora Tahun 2000-2008. In Workshop Forum Peneliti di Lingkungan Kemendiknas (pp. 472-490). Yogyakarta: Badan Penelitian dan Pengembangan Kementerian Pendidikan Nasional.

Teeuw, A. (1989). Sastra Indonesia Modern II (I). Bandung: PT Karya Nusantara. 